\title{
Structure and High-Temperature Decomposition Process of $\mathrm{LiNiO}_{2}$
}

\author{
Ryoji KANNO*, Hiromichi KUBO, Yoji KAWAMOTO and Yasuo TAKEDA \\ Received July 16, 1993 ; Accepted August 17, 1993
}

\section{INTRODUCTION}

The layered nickel oxides $\mathrm{LiNiO}_{2}$ have been studied for possible use as insertion electrodes in $4 \mathrm{~V}$ rechargeable lithium batteries ${ }^{1-3)}$. In $\mathrm{LiNiO}_{2}$, alternate layers of $\mathrm{Li}$ and $\mathrm{Ni}$ occupy the octahedral sites of a cubic close packing of oxide ions, making up a rhombohedral structure with a $\mathrm{R} 3 \mathrm{~m}$ space group, $\mathrm{Li}$ in $3 \mathrm{a}, \mathrm{Ni}$ in $3 \mathrm{~b}$ and $\mathrm{O}$ in $6 \mathrm{c}$ sites. This compound shows structural and compositional varieties depending on their synthesis conditions. The stoichiometric $\mathrm{LiNiO}_{2}$ is difficult to obtain, because the hightemperature treatment of $\mathrm{LiNiO}_{2}$ leads to a decomposition from $\mathrm{LiNiO}_{2}$ to $\mathrm{Li}_{1-x} \mathrm{Ni}_{1+x} \mathrm{O}_{2}$ which has a partially disordered cation distribution at the $\mathrm{Li}$ site ${ }^{4,5}$ ). The stoichiometry of $\mathrm{LiNiO}_{2}$ affects the physical properties; the nonstoichiometry led to a significant degradation on the charge and discharge characteristics ${ }^{6}$ and the magnetic properties were extremely sensitive for its cation distribution ${ }^{7,8)}$. In the present study, we examined precisely the decomposition process from $\mathrm{LiNiO}_{2}$ to $\mathrm{Li}_{1+x} \mathrm{Ni}_{1+x} \mathrm{O}_{2}$ at high temperatures. We synthesized " $\mathrm{LiNiO}_{2}$ " which is very close to the stoichiometric composition; its structure was determined by the neutron diffraction measurement.

\section{EXPERIMENTAL}

The ternary oxide $\mathrm{LiNiO}_{2}$ was prepared by heating an appropriate molar ratios of $\mathrm{Li}_{2} \mathrm{O}_{2}$ and $\mathrm{NiO}\left(\mathrm{Li}_{2} \mathrm{O}_{2}\right.$ : Alfa Ltd., $>95.3 \%$ purity; NiO: Nakarai tesk, $>99.9 \%$ purity). They were mixed, pelletized in an argon filled glove-box, and then heated in the range of $450-850^{\circ} \mathrm{C}$ under oxygen gas flow. X-Ray diffraction patterns of the powdered samples were obtained with an X-ray diffractometer (Rigaku RAD-C) with CuK $\alpha$ radiation. The lattice parameters were refined by Rietveld analysis using the computer program RIETAN9). Neutron diffraction data were taken on a TOF neutron powder diffractometer, HRP'0), at the KENS pulsed spallation neutron source at the National Laboratory for High Energy Physics (KEK). The electrochemical tests were carried out using lithium cells with 2016 coin-type configuration. Typical electrolytes used were $1 \mathrm{M}$ solutions of $\mathrm{LiClO}_{4}$ in a 50:50 mixture of propylene carbonate(PC) and 1,2-dimethoxyethane (DME) (Mitsubishi petrochemical company Ltd., battery grade) by volume. The reaction and weight loss of the lithium

Department of Chemistry, Faculty of Science, Kobe University, Kobe, Hyogo, 657 Japan, 'Department of Chemistry, Faculty of Engineering, Mie University, Tsu, Mie, 514 Japan Key words: Lithium cell, Cathode, Neutron diffraction. nickel oxides on heating up to $1000^{\circ} \mathrm{C}$ were measured by an automatic differential thermal analysis-thermogravimetry (DTA-TG) apparatus of Rigaku TAS-100.

\section{RESULTS AND DISCUSSION}

We synthesized the samples according to the method of Thomas et al. 1$)$. The reactions in an oxygen gas flow at $650-850^{\circ} \mathrm{C}$ for $48 \mathrm{~h}$ gave the rhombohedral $\mathrm{LiNiO}_{2}$; only a mixture of $\mathrm{Li}_{2} \mathrm{NiO}_{3-y}{ }^{11)}$ and $\mathrm{NiO}$ was obtained below $500^{\circ} \mathrm{C}$. The lattice parameters of the reaction products after the $\mathrm{X}$-ray Rietveld refinement increase slightly from $a=2.87584(6)$ and $c=14.1905(4) \AA$ at $650^{\circ} \mathrm{C}$ to $a=$ $2.87899(5)$ and $c=14.1922(4) \AA$ at $850^{\circ} \mathrm{C}$. The increase in the lattice parameters with reaction temperature indicates a decomposition of $\mathrm{LiNiO}_{2}$ to $\mathrm{Li}_{1-x} \mathrm{Ni}_{1+x} \mathrm{O}_{2}$ at higher temperatures ${ }^{2}$. The compositions determined by atomic absorption spectroscopy were $\mathrm{Li}_{0.99} \mathrm{Ni}_{1.01} \mathrm{O}_{2}\left(\mathrm{Ni}^{2.98+}\right)$, $\mathrm{Li}_{1.00} \mathrm{Ni}_{1.00} \mathrm{O}_{2}\left(\mathrm{Ni}^{3.00+}\right)$, and $\mathrm{Li}_{0.93} \mathrm{Ni}_{1.07} \mathrm{O}_{2}\left(\mathrm{Ni}^{2.87+}\right)$ for the samples synthesized at 650,700 and $850^{\circ} \mathrm{C}$, respectively.

Neutron diffraction data were obtained for the sample synthesized at $700^{\circ} \mathrm{C}$ in an oxygen gas flow. The structure was refined with space group $\overline{\mathrm{R}} \overline{\mathrm{m}} \mathrm{m}$ with the structural model, $\mathrm{Li}$ at $3 \mathrm{a}(0,0,0)$, Ni at $3 \mathrm{~b}(0,0,1 / 2), \mathrm{O}$ at $6 \mathrm{c} .(0,0$, $z$ ) with $z \approx 0.25$. The partial disordering of $\mathrm{Li}$ and $\mathrm{Ni}$ at the $\mathrm{Li}(3 \mathrm{a})$ and $\mathrm{Ni}(3 \mathrm{~b})$ sites was considered with a constraint that the total occupancy at each site is unity. Table I lists final $R$ factors, lattice and structural parameters, and their estimated standard deviations. The best fit between observed and calculated data in $\mathrm{LiNiO}_{2}$ synthesized at $700^{\circ} \mathrm{C}$ yielded the $\alpha-\mathrm{NaFeO}_{2}$ structure in which the $3 \mathrm{a}$ and $3 \mathrm{~b}$ octahedral sites were mainly occupied by lithium and nickel ions, respectively. The interstitial tetrahedral site $\mathrm{Ni}(3)$ at a position $(0,0,-1 / 8)$ is situated in the $\mathrm{NiO}_{6}$ octahedral layers. Attempts to refine the occupancy of this site led to an insignificant site occupancy of $0.002(2)$. Finally, the refined composition $\mathrm{Li}_{0.996} \mathrm{Ni}_{1.006} \mathrm{O}_{2}$ is in excellent agreement with the expected $\mathrm{LiNiO}_{2}$ stoichiometry.

The reversibility of the lithium cell, $\mathrm{Li} / \mathrm{LiNiO}_{2}$, was examined using " $\mathrm{LiNiO}_{2}$ " prepared at 650, 700 and $850^{\circ} \mathrm{C}$. The current density was $0.75 \mathrm{~mA} / \mathrm{cm}^{2}$ and the cut-off voltages were $2.5 \mathrm{~V}$ for discharge and $4.3 \mathrm{~V}$ for charge, respectively. A specific capacity of about 150 $\mathrm{mAh} / \mathrm{g}$ was obtained for the cells with the cathodes prepared at 650 and $700^{\circ} \mathrm{C}$. However, a lower capacity of about $130 \mathrm{mAh} / \mathrm{g}$ was observed for the cathode prepared at $850^{\circ} \mathrm{C}$. The cation disordering on the octahedral sites 
Table I Structural Parameters for $\mathrm{LiNiO}_{2}$ in $\mathrm{R} 3 \mathrm{~m}(T=300 \mathrm{~K})$

\begin{tabular}{|c|c|c|c|c|c|c|}
\hline \multicolumn{7}{|c|}{$\begin{array}{l}a=2.87799(8) \AA, c=14.1953(3) \AA \\
\left(R_{\mathrm{wp}}=3.65 \%, R_{\mathrm{p}}=2.82 \%, R_{l}=2.64 \%, R_{F}=1.65 \%, \mathrm{~S}=R_{\mathrm{wp}} / R_{\mathrm{e}}=1.17\right) \\
\text { Atom Site } g \quad x \quad y \quad z \quad B / \AA^{2}\end{array}$} \\
\hline $\mathbf{L i}$ & $3 a$ & $0.996(5)$ & 0 & 0 & 0 & $1.6(2)$ \\
\hline $\mathrm{Ni}(1)$ & $3 a$ & 0.004 & 0 & 0 & 0 & 1.6 \\
\hline $\mathrm{Ni}(2)$ & $3 b$ & 1.0 & 0 & 0 & $1 / 2$ & $0.31(2)$ \\
\hline $\mathrm{Ni}(3)$ & $6 c$ & $0.002(2)$ & 0 & 0 & 0.131 & 0.31 \\
\hline 0 & $6 c$ & 1.0 & 0 & 0 & $0.24111(16)$ & $0.86^{\mathrm{a})}$ \\
\hline Atom & $U_{11} / \AA$ & & & & $U_{12} / \AA^{2}$ & $U_{13} / \AA^{2} \quad U_{23} / \AA^{2}$ \\
\hline 0 & 0.011 & $10(6)=U$ & & & $770(6)=U_{11} / 2$ & 0 \\
\hline
\end{tabular}

a) Equivalent isotropic thermal parameters, $B_{\mathrm{eq}}$.

affects the reversibility as indicated by the previous studies ${ }^{5,6)}$.

The TG curve in an oxygen gas flow showed a slight weight gain around $800^{\circ} \mathrm{C}$, and then showed a large decrease in weight around $920^{\circ} \mathrm{C}$ accompanied by an endothermic DTA peak. The X-ray diffraction pattern of the sample after the DTA-TG measurement was indexed by a cubic cell of $a=4.1231(15) \AA$, indicating a decomposition of $\mathrm{LiNiO}_{2}$ to $\mathrm{Li}_{x} \mathrm{Ni}_{1-x} \mathrm{O}$. The decomposition temperature shifts from $920^{\circ} \mathrm{C}$ in $\mathrm{O}_{2}$ atmosphere to $750^{\circ} \mathrm{C}$ in Ar atmosphere, indicating that the decomposition from $\mathrm{LiNiO}_{2}$ to $\mathrm{Li}_{x} \mathrm{Ni}_{1-x} \mathrm{O}_{2}$ was suppressed with increasing oxygen partial pressure in the measurement atmosphere.

To understand the reaction mechanism at higher temperatures, we examined the decomposition process by annealing samples in air or in an oxygen gas flow at various temperatures. The samples synthesized at $850^{\circ} \mathrm{C}$ were annealed at $300,450,600,700,850$, and $1000^{\circ} \mathrm{C}$ in air or in an oxygen gas flow and then quenched into liq. $\mathrm{N}_{2}$. The structural parameters of these samples were refined using the structural models as follows: the cubic $\mathrm{Li}_{x} \mathrm{Ni}_{1-x} \mathrm{O}$ with disordering cation distribution (space group $\mathrm{Fm} 3 \mathrm{~m}$ ) for the $1000^{\circ} \mathrm{C}$ sample; the rhombohedral $\mathrm{Li}_{1-x} \mathrm{Ni}_{1+x} \mathrm{O}_{2}$ with partial disordering at the $\mathrm{Li}$ site (space group $\mathrm{R} \overline{3} \mathrm{~m}$ ) for the samples below $700^{\circ} \mathrm{C}$; a mixture of the cubic Fm $3 \mathrm{~m}$ and the rhombohedral $\mathrm{R} 3 \mathrm{~m}$ phases for the $850^{\circ} \mathrm{C}$ sample. Figure 1 shows the annealing temperature dependence of the lattice parameters for " $\mathrm{LiNiO}_{2}$ ". The lattice parameters of the rhombohedral $\mathrm{R} 3 \mathrm{~m}$ phase increase with annealing temperature from 600 to $850^{\circ} \mathrm{C}$ in air. The rhombohedral phase decomposed to the cubic $\mathrm{Fm} 3 \mathrm{~m}$ phase above $850^{\circ} \mathrm{C}$. The lithium occupancy rate at the $\mathrm{Li}$ site, shown in Fig. 1, also decreases with annealing temperature. On the other hand, only a slight increase in the rhombohedral (hexagonal) lattice parameters and no decomposition to the cubic phase were observed for the samples annealed below $850^{\circ} \mathrm{C}$ in an oxygen gas flow, being consistent with our TG results that the decomposition temperature shifted to higher temperatures with increasing partial oxygen
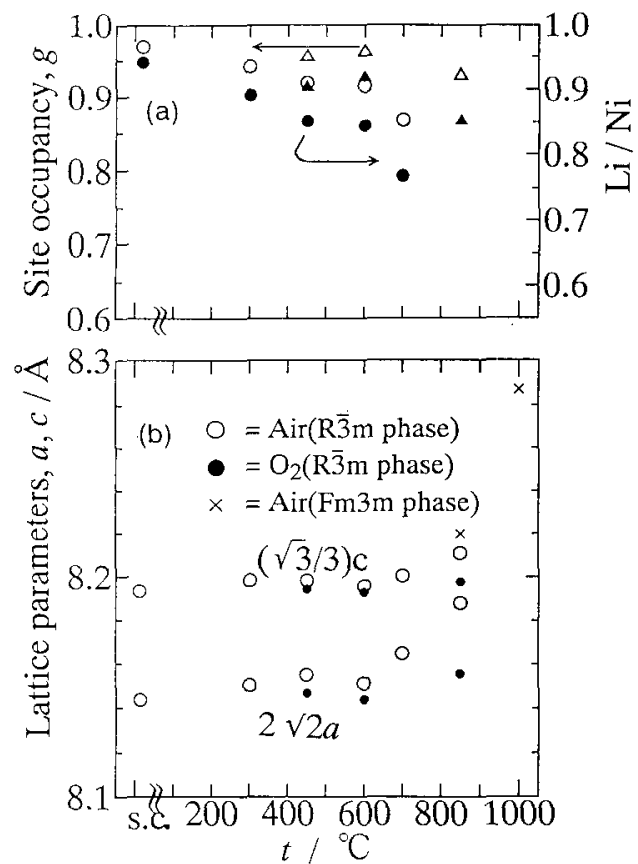

Fig. 1 (a)Annealing temperature dependence of the lithium occupancy rate in the $\mathrm{Li}$ site, and $\mathrm{Li} / \mathrm{Ni}$ ratio; $g$ values for the samples annealed in $\mathrm{O}_{2}(\Delta)$ and in air (O); $\mathrm{Li} / \mathrm{Ni}$ ratios for the sample annealed in $\mathrm{O}_{2}(\Delta)$ and in air( $\bullet$ ). S.C. indicates the samples cooled siowly from $850^{\circ} \mathrm{C}$ in $\mathrm{O}_{2}$ atmosphere. (b) Annealing temperature dependence of the lattice parameters in $\mathrm{LiNiO}_{2}$.

pressure in the measurement atmosphere. The oxidizing condition suppressed the decomposition of $\mathrm{LiNiO}_{2}$ and the reduction from $\mathrm{Ni}^{3+}$ to $\mathrm{Ni}^{2+}$ state.

\section{REFERENCES}

1) M. G. S. R. Thomas, W. I. F. David, J. B. Goodenough, and P. Groves, Mater. Res. Bull., 20, 1137 (1985).

2) J. R. Dahn, U. von Sacken, and C. A. Michal, Solid State Ionics, 44, 87 (1990).

3) J. R. Dahn, U. von Sacken, M. W. Juzkow, and H. AlJanaby, J. Electrochemical Soc., 138, 2207 (1991).

4) J. Morales, C. Perez-Vicente, and J. L. Tirado, Mater. Res. Bull., 25, 623 (1990).

5) W. Li, J. N. Reimers, and J. R. Dahn, Phys. Rev. B46, 3236 (1992).

6) T. Ohzuku, H. Komori, M. Nagayama, K. Sawai, and T. Hirai, Chem. Express, 6, 161 (1991).

7) J. P. Kemp, P. A. Cox, and J. W. Hodby, J. Phys., Condens. Matter, 2, 6699 (1990).

8) K. Hirota, H. Yoshizawa and M. Ishikawa, J. Phys., Condens. Matter, 4, 6291 (1992).

9) F. Lzumi, "The Rietveld Method," ed. by R. A. Young, Oxford Univ. Press, Oxford(1993), Chap. 13.

10) N. Watanabe, H. Asano, H. Iwasa, S. Satoh, H. Murata, K. Karahashi, S. Tomiyoshi, F. Izumi, and K. Inoue, Jpn. J. Appl. Phys. 26, 1164 (1987).

11) H. N. Nigeon, A. Courtois, M. Zanne, and C. Gleitzer, Rev. Chim. Miner., 13, 1 (1976). 